\title{
U.S. Military Ownership
}

National Cancer Institute

\section{Source}

National Cancer Institute. U.S. Military Ownership. NCI Thesaurus. Code C133358.

Operated by the U.S. Military and receives federal government funding. 